\title{
GIS Based Solar Resource Analysis for Irrigation Purposes: Rural Areas Comparison under Groundwater Scarcity Conditions
}

\author{
Á.Rubio-Aliaga ${ }^{\mathrm{a}}$, J.M.Sánchez-Lozano ${ }^{\mathrm{b}}$, M.S. García-Cascales ${ }^{\mathrm{c}}$, M.Benhamou ${ }^{\mathrm{d}}$, A.Molina-García ${ }^{\mathrm{a}}$ \\ ${ }^{a}$ Dept. of Electrical Eng. Universidad Politécnica de Cartagena (UPCT), Murcia, Spain. \\ ${ }^{b}$ Centro Universitario de la Defensa. Academia General del Aire. Universidad Politécnica de Cartagena (UPCT), San Javier, Murcia, \\ Spain. \\ ${ }^{c}$ Dpto de Electrónica, Tecnología de Computadoras y Proyectos. Universidad Politécnica de Cartagena (UPCT), Murcia, Spain. \\ ${ }^{d}$ Laboratoire de Physique des Matériaux et Modéalisation des Systèmes, Université Mouslay Ismail, Ecole Nationale Supérieure d'Arts et \\ Métiers de Meknés, Morocco.
}

\begin{abstract}
During the past decade, most governments have been promoting energy efficiency programs and the integration of renewable energy sources into the majority of energy uses. Among the diferent sectors, the agricultural sector is becoming a more active participant to reduce fossil fuel dependence and improve environmental sustainability. Indeed, agriculture usually combines both a high energy demand and water problems associated with over-exploited aquifers, providing great potential and remarkable opportunities to change the energy mix and maximize the use and integration of natural resources in a rational way. Considering this framework, the present paper describes and compares the solar resource integration and its effects on agricultural pumping purposes in two Mediterranean countries, Spain and Morocco, with significant differences in terms of energy mix, climatic conditions and energy policies. As a novel contribution in this paper, we propose the use of GIS to analyze the spatial and temporal variability of the solar resource through real data of both locations, as well as to study groundwater resources. With this aim, two technical proposals for irrigation purposes are compared in terms of environmental benefits, $\mathrm{CO}_{2}$ emissions and agriculture energy model changes: diesel equipment and photovoltaic system. Results based on solar radiation resource, pumping requirements and aquifer depth are included in the paper.
\end{abstract}

Keywords: Solar Energy Resource, Applicability Solar Energy, Solar Water Pumping, Sustainable Rural Development, Geographic Information Systems (GIS), Photovoltaic Systems.

\section{Introduction}

Fossil fuels have met most energy needs since the $1^{\text {st }}$ Industrial Revolution, providing remarkable industrial advances in newly developing countries. These changes had significant influences on most sectors, including the modernization and industrialization of agricultural processes: tasks related with growing, harvesting, processing or delivering became high energy-demanding. During the $2^{\text {nd }}$ Industrial Revolution, both fossil fuel dependence and energy consumption were increasing considerably. Industrial and developing countries then continued to meet their energy needs by expanding the supply-base, without regard for efficient use or sustainability [1]. Nowadays, the world energy demand increased at a rate of $5 \%$ in 2010, and according to the International Energy Agency (IEA) it will continue increasing until 2050 [2]. This tendency is also motivated by the recent industrialization of countries where demography has soared along with their development, such as China or India [3]; involving further depletion of energy resources and uncertain scenarios for fossil fuel prices and energy demand [4. As a consequence, energy is currently at the core of the discussion, since energy production and use account for two-thirds of the world's greenhouse-gas emissions [2], certain dependency can be established between the use of fossil fuels and global warming problems. Indeed, emissions have been traditionally linked to $\mathrm{SO}_{2}$ and $\mathrm{CO}_{2}$ concentrations, which are considered relevant variables to characterize the greenhouse effect [5].

Taking the finite fossil energy resources into account as well as the severity of pollution emissions, several countries have promoted initiatives related to renewable source integration and the promotion of a more sustainable environment. The main objective is to move from a high $\mathrm{CO}_{2}$ emission mix generation towards a low-emission model, maintaining long-term sustainable economic and social development [6]. Different programs have been promoted with this aim, such as the United Nations Environment Programme (UNEP), the World Meteorological Organization (WMO) and the Intergovernmental Panel on Climate Change (IPCC). In addition, a series of sustainable policies and strategies have been proposed to give an international support, including both the Kyoto Protocol and European Union policies [7]. The use of renewables 
throughout Europe and elsewhere in the rest of the world complies with clear objectives for energy saving and emission reduction [8]. In reference to the road-map of renewables in Spain, significant results have been obtained as a result of subsidies and policies contributing to provide suitable conditions for the integration of renewable solutions, such as PER 2005-2010 9] and PANER 2011-2020 10] promoted by IDAE (Spanish Institute for the Energy Diversification) 11. Additionally, and due to the continued implementation of policies supporting renewable energies in the European Union, around $12 \%$ of the total energy in Spain is provided by renewables, with $20 \%$ of energy from renewable sources being established by 2020 and considerably reducing greenhouse gas emissions. The location of Spain contributes significantly to the high levels of solar radiation, supposing a clear advantage for the integration of solar PV solutions 12. However, and despite Morocco having favorable conditions of solar radiation and also wind resource, the low price of electricity and fuel supposes a major drawback for the integration of renewables in this North African country. In fact, this sector is currently becoming strategic and relevant for the government in Morocco, especially for the large scale integration of solar thermal and wind power solutions 13 .

Agriculture in both countries has been modernized and upgraded with more and more energy requirements, usually supplied by fossil fuels. In Spain, a specific subsidized diesel for agriculture is available for the sector. In Morocco, fuel is not differentiated depending on applications and uses, with the price being considerably lower than in Spain. Therefore, solutions based on diesel equipment still remain as a very common practice for pumping groundwater purposes. Under this scenario, agricultural emissions have been increased from 4.7 billion tons of carbon equivalent $\left(\mathrm{CO}_{2}\right.$ eq) in 2001 to more than 5.3 billion tons in 2011 14. Moreover, the equipment usually used in the agriculture sector commonly presents low energy efficiencies and other factors such as obsolescence, and wear and tear. On the other hand, there are well-known water scarcity problems in both Mediterranean countries. For the specific aquifers to be analyzed, an over-exploitation situation of aquifers has been detected, where farmers are using a larger and larger share of their profits to afford fuel for pumping purposes. To provide an alternative solution for the agriculture sector, and according to current programs promoting the integration of renewables, a conversion of irrigation systems from fossil fuel to solar energy source should be addressed [15] [16, 17]. These initiatives lead to a sustainable environment, providing environmental and social-economic benefits [18, at local and regional levels 19. Among the different resources, solar energy has been widely extended as an alternative resource during the last decades. Both efficiency improvements and process optimization in Silicon production and manufacture have become a mature industry, supporting a high demand of $\mathrm{PV}$ modules and reducing the $\mathrm{Wp}$ price to lower than 0.5 Euro/Wp. Consequently, solar resource is considered as an alternative and competitive solution 20, 21. With the aim of exploring the solar resource in detail, a Geographical Information System (GIS) is proposed in this paper to integrate, analyze and efficiently represent geographical information and physical conditions. The GIS application allows us to depict the solar radiation spatial variability due to the topography of the area 22] under different levels: global, regional or local level. Indeed, the success and competitiveness level of solar technology is based on analyzing the available solar resource throughout its temporal, spatial and spectral characteristics [23, 24]. Consequently, the geographical analysis of the solar resource in these two Mediterranean areas provides significant information regarding the solar resource distribution. A suitable evaluation model is proposed taking into account geographical characteristics, optimal locations for solar energy solutions, environmental concerns, as well as socialeconomic factors associated with solar resource integration into agriculture [25, 6]. In addition, the combination of solar energy with other energy sources (hybrid applications) is also considered by including feasibility and cost analysis 26, 22]. According to the specific literature, different contributions about solar atlas and solar pumping can be found aiming to analyze the viability of these systems [23. Previous GIS application studies are focused on discussing the vulnerability of aquifers or their emissions, including solar resource evaluation [27]. However, there is a lack of contributions addressed to jointly evaluating solar and water resources in the agricultural sector [28, being desirable to include $\mathrm{CO}_{2}$ emission reductions. In [29], the feasibility or alternative solutions are analyzed from several aspects: technical, economic and environmental; without including GIS technical and economic information nor analyzing the applicability concept of solar resource in the studied field. In comparison with recent studies, 29, the present paper focuses on an exportable and flexible methodology based on a GIS solution, which provides an extensive solar resource analysis in an easily understandable manner thanks to software at regional scale.

The rest of the paper is structured as follows: Section 2 describes the energy requirements and solar resource potential in agriculture for the selected areas, including geographical description and water resources for both locations and countries. The proposed methodology is described in Section 3, where the collected data are analyzed from a statistical, geographical and technical point of view. Results are discussed in Section 4. Finally, the conclusion is given in Section 5 .

\section{Energy Requirements and Solar Resource Po- tential in Agriculture: a Mediterranean Case Study}

\subsection{Location of Areas: General Description}

From the geographical and geological point of view, the study region of La Mancha (Spain) is a vast plain (around 
Location of study areas

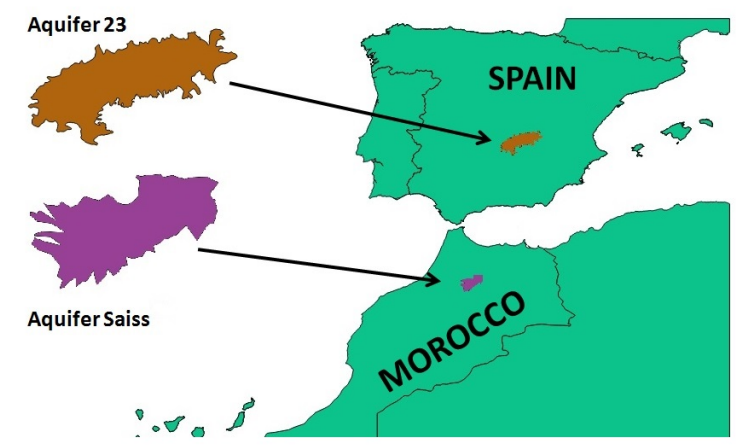

Figure 1: Location of study areas: La Mancha (Spain) and the Saiss plain (Morocco)

$5500 \mathrm{~km}^{2}$ ) dependent on Aquifer 23 (04.04 hydrogeological unit or the Western-La Mancha). It is located in the Central area of the high Guadiana river, a sedimentary basin mainly dominated by a limestone ('karst') region [30, 31. The relief of the Morocco region, the Saiss plain (2100 $\mathrm{km}^{2}$ ) 32, also known as the Fez-Meknes plain, resembles the La Mancha plain on karst [33, 34, 32. Regarding weather conditions, La Mancha area is considered as a continental Bsk Mediterranean climate (Köppen-Geiger climate classification), typically associated with dry and hot summers (over $43^{\circ} \mathrm{C}$ ) and high solar radiation levels (over $4500 \mathrm{kWh} / \mathrm{m}^{2}$ per day), as well as cold winters with most days below $0^{\circ} \mathrm{C}$, see Figure 1 for geographical location. A significant low rain-fall (between 300-400 mm) and very high evaporation during most months clearly reflect the arid climate conditions in this Spanish area. The Saiss region has a Csa Mediterranean climate (Köppen-Geiger climate classification), with annual average temperatures about $17.3^{\circ} \mathrm{C}$ [32], dry and very hot summers (over $40^{\circ} \mathrm{C}$ ) and also with high solar radiation levels. By contrast, winters are milder than in the Spanish region, and winter and spring seasons present higher rainfall values (490-560 $\mathrm{mm}$ per year) [32. This region can be thus classified as a semiarid-zone according to the Martonne index.

In the region of La Mancha (Spain), the Aquifer 23 mainly comprises medium-sized cities, accounting for fewer than 400000 people, with a low population concentration and minor requirements supported by the aquifer. However, in the Maghreb region, the population is over 1.5 million of people, thus increasing the requirements on the Saiss aquifer in comparison with the Aquifer 23. Both areas belong to the Mediterranean agricultural landscape: olives, wheat and grapes; as well as other tree dry land crops (almonds, figs...) and small orchards (fruit, vegetables... ) In particular, La Mancha Region offers a remarkable example of vast plains and dry land, supporting irrigation crops during the last centuries. In the area located in Meknes (Morocco), agriculture contributes significantly to economic aspects by promoting jobs and improving rural incomes 35. The landscape is still dominated by wheat, along with irrigation of vegetables, total $45 \%$, and fruit (citrus, olive and vine) with 36\% 35. The area comprises an agricultural surface area of approximately $191000 \mathrm{Ha}$, around $80 \%$ of the total area. The irrigation crops account for less than a quarter of the land use (about $37000 \mathrm{Ha}$ ), the land with irrigation potential commissioning is over $123000 \mathrm{Ha} 35$.

\subsection{Water Resources for Irrigation Purposes}

The Mediterranean region is undergoing rapid local and global social and environmental changes. All indicators point to an increase in environmental and water scarcity problems with negative implications towards current and future sustainability 36. The risk of water scarcity is proposed to be managed by preparedness rather than by a crisis approach, along with the importance of local management at basin scale 37. Moreover, several researchers have even pointed out the links between social-political relations and water management, including power-plays in irrigation policies [38, 39, 40]. In both areas, irrigation is a crucial aspect directly linked to the agricultural production and with significant impact on the environment. In Spain, the awareness to natural resources and agricultural modernization has led to irrigation methodologies based on drip and sprinkler solutions. However, gravity irrigation methods still remain in Morocco, being at this moment the most popular solution. In both cases, high water demand and inefficient irrigation methods should be improved, proposing alternative solutions in line with the hydrological cycle characteristics of the area. Additionally, unsustainable irrigation patterns should be modified, promoting new policies from government and organizations responsible for the care of water resources [4]. In this way, the groundwater levels have dropped dramatically during the last years, with scarcity problems and difficulties to reconcile agriculture with the environment.

In La Mancha (Spain), the piezometric evolution of Aquifer 23 during the period 1980-2008 can be summarized as a sort of declining level periods, with the presence of notable but isolated partial recovering intervals mainly due to wet periods, see Figure 2 42, 43. As a consequence of a continuous over-exploitation of the Aquifer, pumping is currently the only way to extract water [4]. Therefore, rigid constraints and requirements have been issued for irrigation, such as a maximum of $1500 \mathrm{~m}^{3} /$ (Ha-per-year) for vineyard crops.

The hydrogeological map of the Saiss aquifer (FezMeknes) was published in 1960 [45]. The Saiss aquifer - with contributions by infiltration of rainwater among other processes of 296-346 million $\mathrm{m}^{3} /$ year - is currently estimated to provide an annual demand between 275 and 400 million $\mathrm{m}^{3}$ /year due to rivers, drought and desiccation of some springs, drinking water and intensive agriculture (mainly since the 1980's). The aquifer currently has water deficit conditions with non-pumping limitations, with the average water demand of crops per hectare being between 

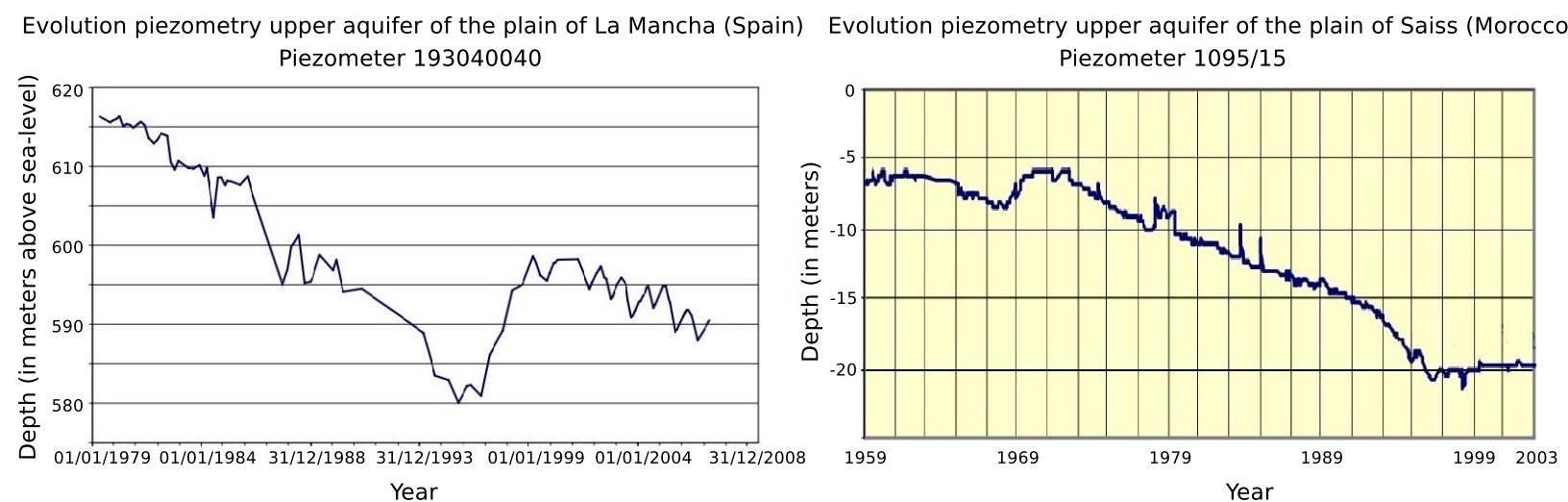

Figure 2: Evolution piezometry upper aquifer of the La Mancha plain (Spain) 42] and the Saiss plain (Morocco) [35]

$3500 \mathrm{~m}^{3} / \mathrm{Ha}$ and $5600 \mathrm{~m}^{3} / \mathrm{Ha}$, see Figure 2 35]. The Saiss aquifer presents a large depth variability as a consequence of geological influences. Indeed, near Fez located at the East of the Ain Taoujdate line, it is over $60 \mathrm{~m}$ deep, even reaching over $350 \mathrm{~m}$ in some piezometers [34]. The chronological evolution of the Saiss aquifer gives a clear imbalance between exploitation and recharge of water resource 33, 34.

\subsection{Energy Requirements and Solar Resource Potential}

Both areas are located in the 'sun belt' area 23. between $40^{\circ} \mathrm{N}$ and $40^{\circ} \mathrm{S}$ latitudes, with high solar radiation levels throughout the year. Spain is a country with a high energy dependence, around $71 \%$ in 2013 of primary energy [46] and $27.3 \%$ of power demand covered by renewables 47. Energy demanded by agriculture was 3.3\% in 2013 of total primary energy, and over $76 \%$ is covered with fossil fuels. As mentioned before, this great energy dependence and the fuel price increasing is leading Spanish agriculture to an unsustainable situation. To overcome these drawbacks, the Spanish government promotes initiatives to subsidize fuel for agricultural applications, as a way to reduce the pressure on Spanish farmers. Until 2011, the Spanish government also financially supported the integration of renewables, with a large economic contribution in $R \& D$. Although the renewable energy sector has always been expanding during the last decades, the crisis has affected it strongly, mainly driven by the reduction of programs and initiatives.

The price of fuel in Morocco is fully regulated by the Moroccan government. In that country, fuel prices are 30-40\% cheaper than in Spain, and a few programs and initiatives can be found to promote the renewable energy source integration, despite Morocco being highly dependent on imported energy, with over $90 \%$ dependence on other countries [4]. Nevertheless, there are few solar thermal systems and photovoltaic installations connected to the grid, and few projects promoting renewable energy source integration. Today, several specialized weather stations can be found in the country. To overcome technological deficiencies, Morocco has already started different initiatives to characterize the solar radiation resource in the country. The objective is to analyze and study accurately the solar resource conditions in each region of Morocco. Nowadays, the Meteorological Institute of Morocco has some weather facilities in different parts of the country, and the IRESEN (L'Institut de Recherche en l'Energie Solaire et Énergies Nouvelles) and MASEN (Moroccan Agency for Solar Energy) are also promoting the installation of new stations for solar radiation studies. In line with the great development of photovoltaic technology, it would be desirable to have an extended knowledge of the geographical distribution and variability of the solar resource [28, 17]. Furthermore, an accurate database of suitable locations for renewable energy facilities is suggested by some authors as a relevant tool to optimize the integration of these renewable solutions [25].

\section{Methodology: GIS Solution for Solar Resource Comparison and Applicability Purposes}

\subsection{Preliminaries}

Energy resources are usually spatially distributed, and GIS applications can be used as suitable solutions providing a logical environment to analyze a variety of spatially related data in a cost-effective way [49]. For the development of the maps, Quantum GIS (QGIS) (version 2.14 ESSEN) was selected by the authors. It is a GIS OpenSource solution, lightweight and with a friendly graphical interface, and is flexible and easy to use. It can be freely installed and modified according to the specific functionality required by the application. It has a great interoperability and works with all operating systems [50, 51. QGIS provides a growing range of capabilities through basic functions and accessories. It also allows to manage, edit and analyze data and design printable maps; performing map algebra, terrain analysis, hydrological models and supports a series of formats of raster and vector data. As remarkable advantages, the possibility of integrating 


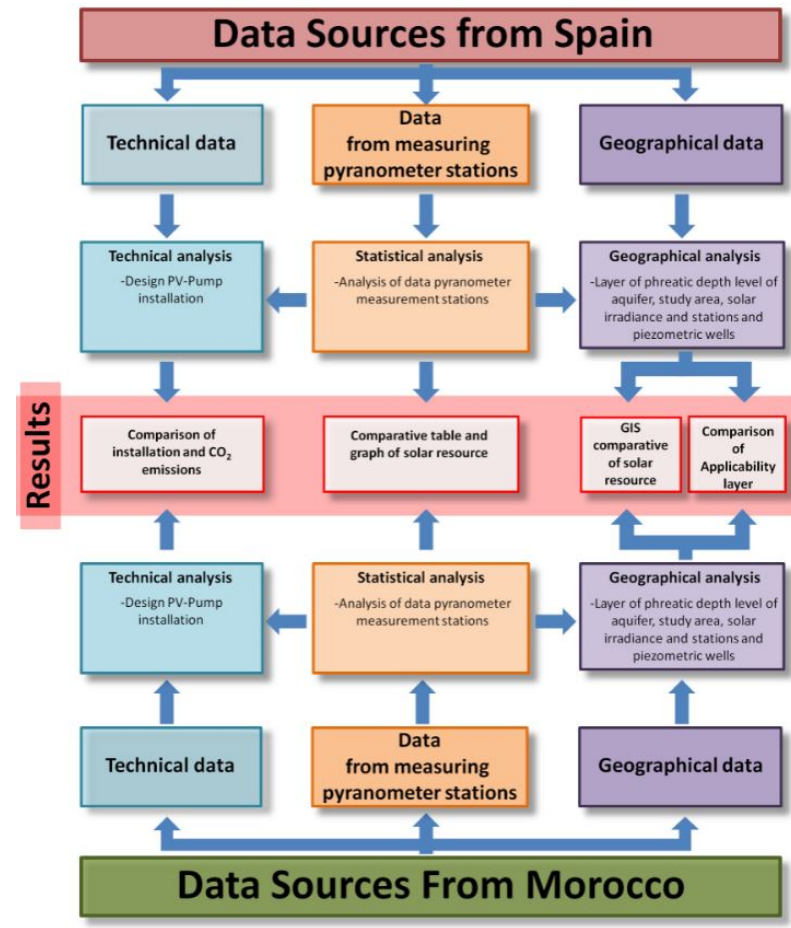

Figure 3: Proposed methodology based on solar resource analysis and comparison for irrigation purposes

GRASS (Geographic Resources Analysis Support System) in QGIS, and the ease connection as PostGIS database can be highlighted.

GIS can handle geo-referenced information to assess technical and economic feasibility of the source exploitation. Since the 1970 s, different contributions have been developed, considerably solving problems in land management, such as evaluation of natural resources, agricultural land management, water management and control, or environmental planning [15, 52, 53]. According to [54], the application of geomatics to renewable resource assessment, in particular to the solar resource, is a topic worth investigating 55. GIS is thus a suitable solution for spatial analysis of solar resources, considering spatial distribution of the potential, dependence on geographical locations, and levels of use according to the technology 6]. Moreover, an effective selection of locations depends on considering several independent factors concerning geomorphology, aquifer depths and solar radiation.

The proposed methodology includes the analysis of three different types of data, which gives an extended comparative of the solar resource possibilities: (i) statistical data of aquifers and solar resource; (ii) geographical data in both areas; and (iii) technical analysis data. As can be seen in Figure 3 the proposed methodology can be summarized as: Comparison of installations and $\mathrm{CO}_{2}$ emissions; Comparative tables and graphs; GIS comparative of solar resource; and Comparison of applicability layer.

\subsection{Data Sources}

In line with the previous section, the Spanish data corresponding to the studied area can be divided into three categories: statistical, geographical and technical data. The solar resource has been provided through SiaR data-base of Castilla La Mancha Region, an agricultural organization in charge of collecting data to provide this information for irrigation purposes (http://crea.uclm.es/siar/). In our case study, a historical series of data from January 2001 to December 2014 is considered with the values in $\mathrm{MJ} / \mathrm{m}^{2}$ per day. The historical data are used to analyze the incident solar resource in the area of the aquifer. Annual data from nineteen stations allow us to determine a detailed map of solar radiation under a GIS environment. Geographic data including the geo-positioning of all pyranometer stations is also available. The solar radiation layer can be matched with data concerning the aquifer, thus it is possible to propose a layer with a GIS area of the aquifer. Another source of data provides the aquifer depth estimated in February 2014 for different points of the study area through information given by 26 piezometric stations with their corresponding UTM (Universal Transverse Mercator) position. This information is supported by the Confederación Hidrográfica del Guadiana, in collaboration with the irrigation Community of Aquifer 23. Figure 4 shows the pyranometer station locations. Similar types of data corresponding to the Morocco location were collected as a result of a collaboration with the Meknes University. A historical solar radiation data series from February 2004 to December 2013 was provided by línstitut de Recherche en Énergie Solaire et en Énergies Nouvelles in Rabat (IRESEN) (http: //www.iresen.org/fr/index.html), in $W h / m^{2}$ per day, corresponding to seven pyranometer stations, see Figure 5.

Geographical data are also available from geo-referenced data stations, including contour and piezometric stations with their UTM locations for the aquifer. These data have been provided by the Agence du Bassin Hydraulique du Sebou (Morocco). Technical data were collected from previous contributions and other installations in a similar way to the Spanish case.

\subsection{Statistical Analysis of Solar Resource}

Solar resource data for both areas are analyzed in detail to determine average monthly data as well as station variability. Firstly, a classification of the data collected in both countries and a selection of common units is carried out. In our case, all data are expressed in $\mathrm{Wh} / \mathrm{m}^{2}$ per day, determining maximum, minimum and monthly average values for each station. Secondly, a summary of variability and range of the data including standard deviation between stations are compared by using monthly values of each year. Data variation between stations is lower than $10 \%$ for both locations. An equivalent average value is considered as valid for all stations, and variability 


\section{Piezometric Stations}

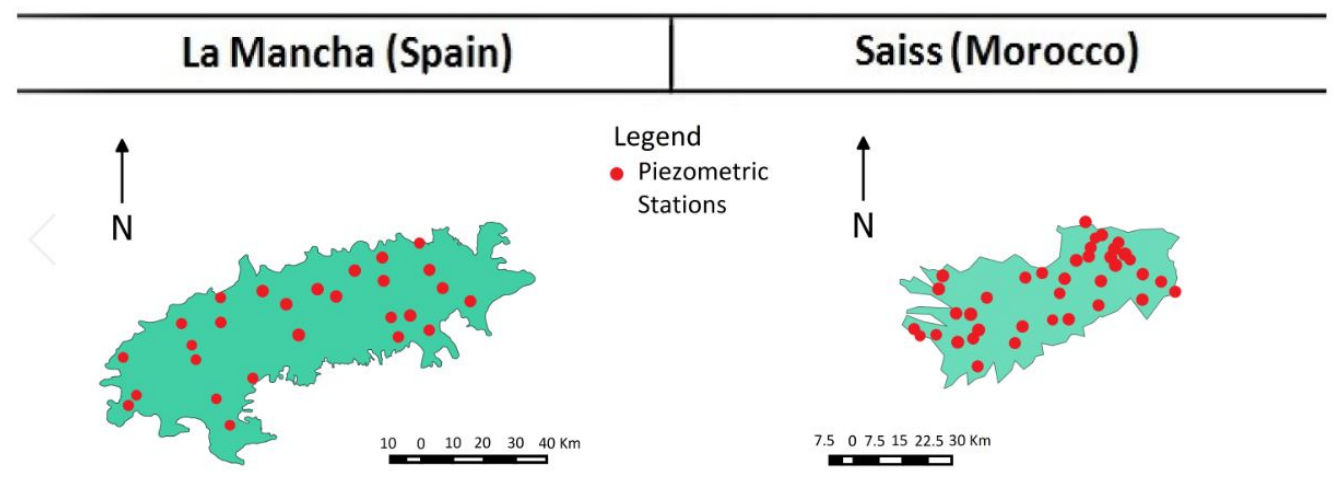

Figure 4: Location of measuring Piezometric Stations by reference to the aquifer

\section{Pyranometer Stations}

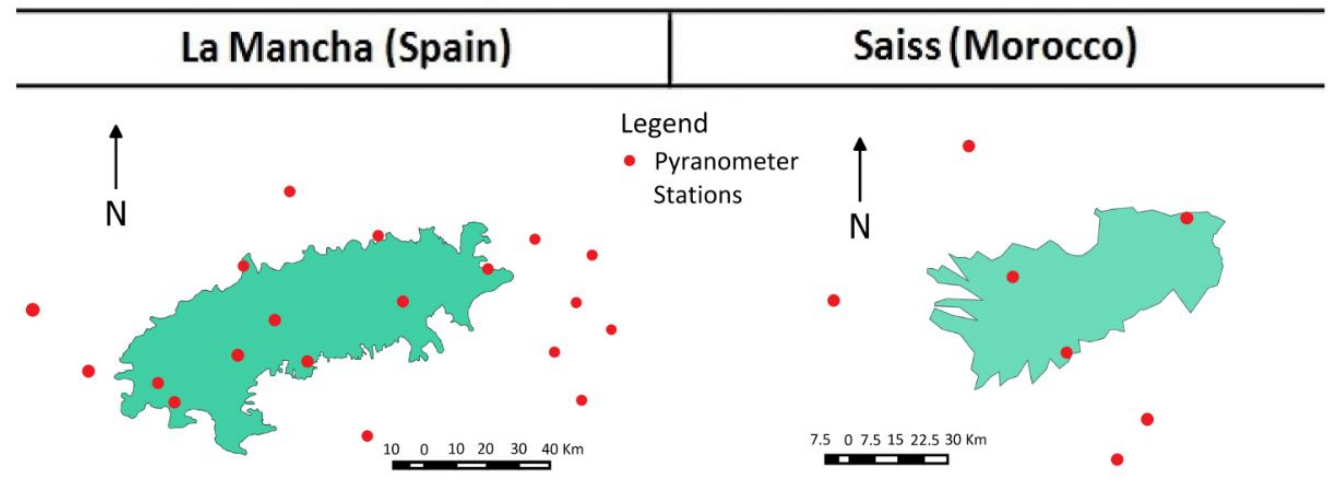

Figure 5: Location of measuring Pyranometer Stations by reference to the aquifer 


\begin{tabular}{|l|r|l|r|}
\hline \multicolumn{4}{|c|}{ Annual average and standard deviation between measurement stations } \\
\hline \multicolumn{1}{|c|}{ La Mancha (Spain) Annual Average } & Saiss (Morocco) Annual Average \\
\hline \multicolumn{1}{|c|}{ Measuring station } & Wh/m m $^{2}$ day & Measuring station & Wh/m m $^{2}$ day \\
\hline Álcazar de San Juan & 4934.01 & Meknes & 5362.14 \\
\hline Argamasilla de Alba & 4941.35 & lfrane & 5358.71 \\
\hline Bolaños & 5001.08 & Fes & 5341.04 \\
\hline Daimiel & 4989.56 & El Hajeb & 5349.67 \\
\hline El Pedernoso & 4816.83 & Azrou & 5339.83 \\
\hline El Sanchón-Vara del Rey & 4971.48 & Khemisset & 5342.83 \\
\hline Herencia & 4940.56 & Sidi Kacem & 5335.39 \\
\hline Juanaco-Villarrobledo & 4759.53 & Stand. Deviation & 10.10 \\
\hline Manzanares & 5084.76 & & \\
\hline La Puebla de Almuradiel & 4826.23 & & \\
\hline La Gineta & 4819.36 & \\
\hline El Picazo & 4816.87 & \\
\hline Tarazona de La Mancha & 4502.81 & \\
\hline Porzuña & 4947.49 & \\
\hline Villanueva de la Jara & 4708.40 & \\
\hline Ciudad Real & 4862.22 & \\
\hline Albacete & 4858.41 & \\
\hline Villahermosa-Tajoneras & 5058.53 & \\
\hline Motilleja & 4798.52 & \\
\hline Stand. Deviation & $\mathbf{1 3 5 . 7 2}$ &
\end{tabular}

Figure 6: Annual average and standart deviation among measurement stations

between stations is also depicted in this study, see Figure 6. From the monthly average values per station, an equivalent average monthly value from all measured stations is estimated to compare both countries. In a similar way, an annual average value is determined for each station, and the corresponding annual equivalent average value can be calculated for each study area and country. The geographical analysis inputs are the monthly average values per station and per country [26, 56.

\subsection{Geographical Analysis of Solar Resource}

With landscape scales, topography is a key factor determining the spatial variability of radiation. Variation in elevation, orientation (slope and aspect), and shadows cast by topographic features all affect the amount of radiation received at different locations 25. The first step is focused on limiting the study area and the extension of both aquifers, based on maps and table information including coordinates of the aquifers provided by the Confederación Hidrográfica del Guadiana (Spain) [43, 44, 57] and the Agence du Bassin Hydraulique du Sebou (Morocco) [58, 59. The estimation of the aquifer outline is related to a dynamic mass of water influenced by two main factors: the high water table and the geological materials that serve the continent, which can be used as waterproofing or otherwise can be permeable and present a very narrow boundary line. Data corresponding to the statistical analysis (monthly and annual solar radiation for each measurement station at their own UTM coordinates) are then exported to the geographical analysis. To give an example of the proposed methodology, only characteristics of representative months are considered in the Results section: January, April, July and October; as well as the annual values offering additional geo-referenced information. Data from piezometers and aquifer depths corresponding to each study area give the groundwater status by a simple yet adequate estimation.
The next step is to determine the aquifer maps and solar radiation distributions corresponding to both locations. The GIS process deals with radiation data and geographical locations to determine the study area layer and estimate the space-temporal data. A depth map of each aquifer is calculated in a similar way [60. Information regarding the aquifer borderlines, solar radiation resource and aquifer depths is then used to determine the distribution of the water resource and energy needs, see Figure 7. The results involve a comparison of both monthly and annual solar resource as well as an applicability layer. This layer provides an index of the applicability as the role of solar radiation resources and the water table, or expressed differently, a map showing the areas with the best sunaquifer conditions to implement a solar pumping system. This map does not indicate the viability of the system as it is necessary to consider other important factors such as crop irrigation, irrigation frequency, energy prices, etc. This technology has already proven its reliability 61.

The IDW (Inverse distance weighting) interpolation method is applied to estimate values between stations. The sampling points are weighted during the interpolation and then the influence of a point relative to another is decreasing with the distance from the new point to be estimated, determining an IDW surface 62. The weighting is assigned to the sampling points using parameters and weighting coefficient modeling how the influence of the weighting decays as the distance to the new point increases. As the ratio increases, the value of the unknown points approximates the value of the closest observation point. It is important to point out that the IDW interpolation method presents several drawbacks: the maximum and minimum values in the interpolated surface can be drawn only at points of sample data. This often results in small peaks and wells around the location of the data.

\subsection{Technical Analysis of Solar Resource}

In addition to the previous analysis, and for a more complete comparison of both areas, an extended study of the agricultural sector is also proposed. Subsequently, and after analyzing the applicability layer, a comparison based on physical data for two installations in terms of $\mathrm{CO}_{2}$ saving emissions and energy needs by using photovoltaic and diesel solutions is carried out. The same Mediterranean crops in these areas are considered, assuming similar surfaces to ensure such comparability. From these areas, crop needs and irrigation profiles for the design of agricultural pumps are determined from both points of view: diesel solution and PV installation.

\section{Results}

\subsection{Statistical Analysis of Solar Resource}

For both study areas, Figure 8 depicts the solar resource values through the statistical analysis. Considering winter months, Morocco has higher solar resorces than Spain. 


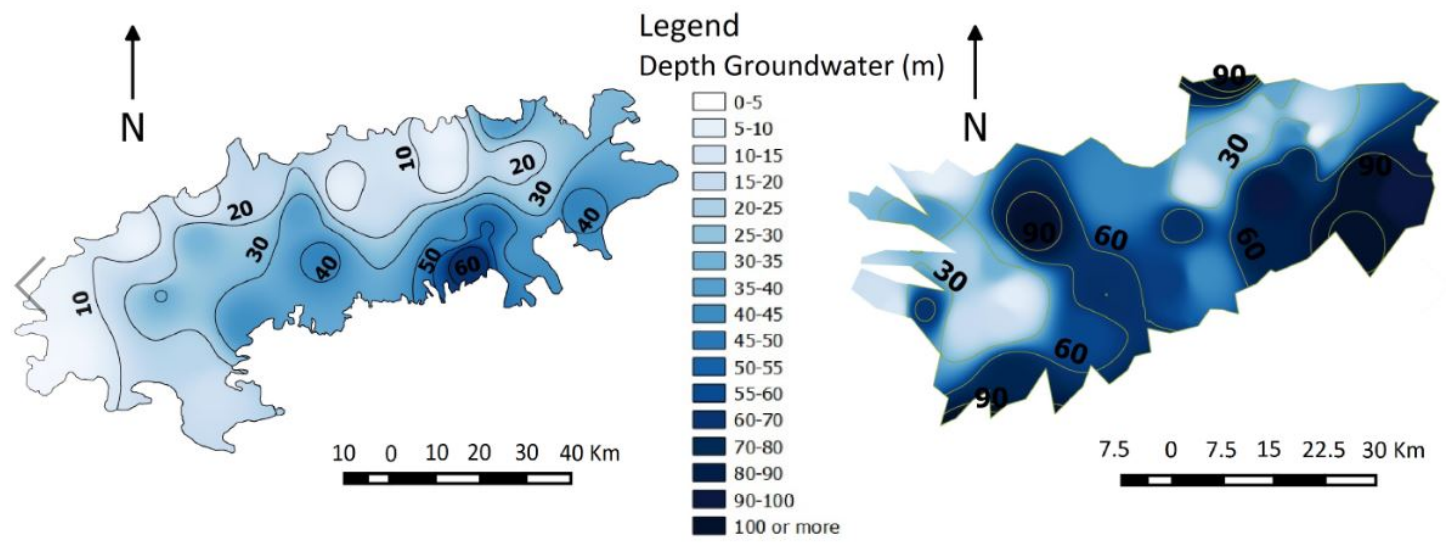

Figure 7: Depth aquifers: distribution of water resource

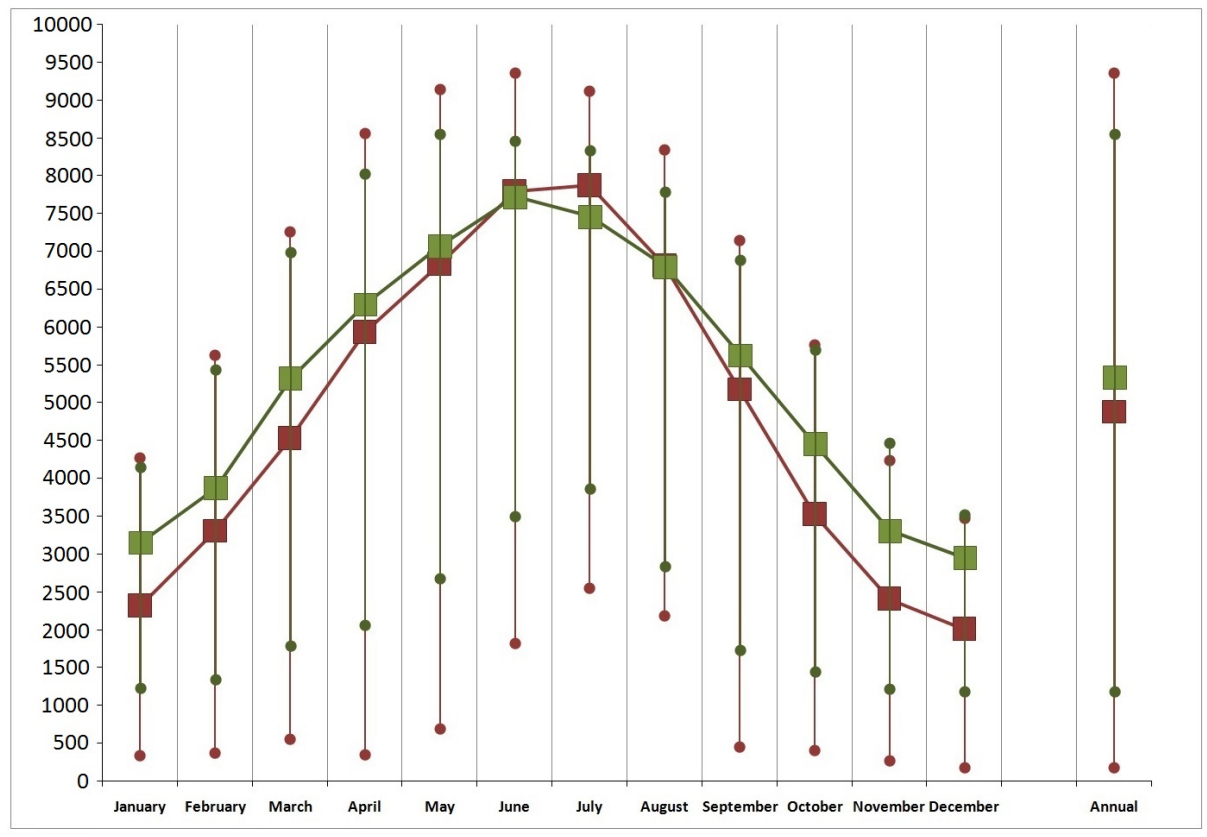

La Mancha (Spain) Monthly Average

Saiss Plain (Morocco) Monthly Average

Solar Irradiance $\mathrm{kWh} / \mathrm{m}^{2} \cdot \mathrm{day}$

Solar Irradiance $k W h / m^{2} \cdot d a y$

Figure 8: Solar resource in both locations: Spain and Morocco 


\begin{tabular}{|c|c|c|c|c|}
\hline \multicolumn{5}{|c|}{$\begin{array}{l}\text { Monthly average, maximum, minimum and standard } \\
\text { deviation of the measurements of each month }\end{array}$} \\
\hline & \multicolumn{4}{|c|}{$\left(\mathrm{Wh} / \mathrm{m}^{2}\right.$ day $)$} \\
\hline La Mancha (Spain) & $\operatorname{Max}$ & Min & Average & Stand. Deviation \\
\hline January & 4271.63 & 336.54 & 2314.47 & 953.98 \\
\hline February & 5628.94 & 369.15 & 3303.81 & 1246.72 \\
\hline March & 7261.54 & 553.65 & 4529.01 & 1556.51 \\
\hline April & 8560.23 & 342.83 & 5935.20 & 1705.69 \\
\hline May & 9139.18 & 686.98 & 6831.77 & 1668.76 \\
\hline June & 9351.75 & 1821.78 & 7793.30 & 1195.70 \\
\hline July & 9114.76 & 2550.43 & 7873.10 & 846.13 \\
\hline August & 8347.51 & 2188.59 & 6813.97 & 1032.04 \\
\hline September & 7142.54 & 451.31 & 5173.06 & 1309.59 \\
\hline October & 5764.91 & 407.89 & 3525.06 & 1180.18 \\
\hline November & 4236.98 & 263.15 & 2409.36 & 919.35 \\
\hline December & 3469.01 & 180.70 & 2006.51 & 816.78 \\
\hline \multirow[t]{2}{*}{ Annual } & 9351.75 & 180.70 & 4875.72 & 309.93 \\
\hline & \multicolumn{4}{|c|}{$\left(\mathrm{Wh} / \mathrm{m}^{2}\right.$ day) } \\
\hline Saiss (Morocco) & $\operatorname{Max}$ & Min & Average & Stand. Deviation \\
\hline January & 4151.67 & 1242.90 & 3162.45 & 746.28 \\
\hline February & 5437.49 & 1354.35 & 3881.83 & 1108.03 \\
\hline March & 6992.61 & 1791.11 & 5331.06 & 1366.01 \\
\hline April & 8030.03 & 2074.28 & 6306.72 & 1546.45 \\
\hline May & 8548.56 & 2679.27 & 7079.09 & 1538.88 \\
\hline June & 8461.54 & 3506.58 & 7727.69 & 975.93 \\
\hline July & 8332.85 & 3869.82 & 7463.24 & 791.98 \\
\hline August & 7788.34 & 2843.63 & 6803.62 & 861.86 \\
\hline September & 6884.35 & 1741.36 & 5635.62 & 1094.86 \\
\hline October & 5699.05 & 1450.01 & 4466.30 & 979.96 \\
\hline November & 4478.39 & 1220.99 & 3318.07 & 843.85 \\
\hline December & 3531.06 & 1195.41 & 2959.33 & 625.32 \\
\hline Annual & 8548.56 & 1195.41 & 5344.58 & 304.05 \\
\hline
\end{tabular}

Figure 9: Monthly, maximum, minimum and standart deviation of the measurement of each month

Spring and autumn months present solar values almost similar in both countries. During the summer, solar radiation levels in Spain are higher than in Morocco, with even more daily sun hours. In terms of average levels, the Spanish annual average is $4.8 \mathrm{kWh} / \mathrm{m}^{2}$ per day, lower than the annual average of Morocco $\left(5.3 \mathrm{kWh} / \mathrm{m}^{2}\right.$ per day), see Figure 9. Regarding the spatial variability among seasons, the Spanish standard deviation is higher (135.74) than in Morocco. This difference is due to the effect of a larger area for the Spanish case, a height difference of $94 \mathrm{~m}$, as well as a distance of around $160 \mathrm{~km}$ between the Spanish western and the eastern part. In Morocco, with 10.10 standard deviation, a smaller study area is considered, with $100 \mathrm{~km}$ width and a difference in elevation of over $200 \mathrm{~m}$.

\subsection{Geographical Analysis of Solar Resource: GIS Com- parison}

Figure 10 compares solar resource data corresponding to different months for both locations. In the Spanish area, a clear distinction between the east and west parts can be observed, with a global variability below 10\%. The east zone presents less solar radiation and coincides with an upper height. In the region of Meknes-Fez (Morocco), the results show a very slight spatial variability in most months with a decreasing radiation in the South part. The East-northeast (ENE) gives less solar radiation and higher values around Meknes. These data provide a spatial variability and distribution of solar resources in both areas. An additional map is shown in Figure 11, where a comparison between average annual solar resource for both study areas is depicted.

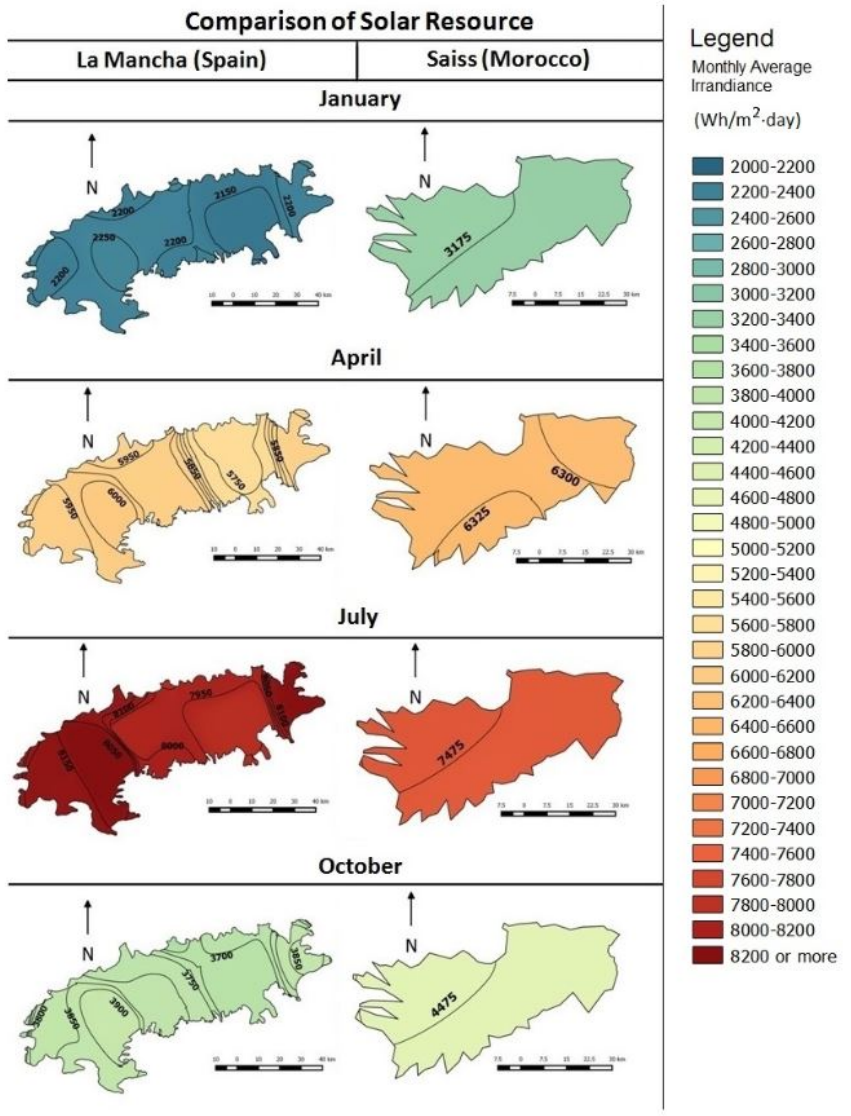

Figure 10: Solar resource for different months: comparison of maps

Figure 12 compares the applicability layers for both study areas. This layer provides an index of applicability associated with the relationship between the solar radiation values and the water level measured in Wh. $\mathrm{m} / \mathrm{m}^{2}$ per day. Through the comparison of these two areas, it can be deduced that solar radiation values are almost constant along the aquifer areas, with the aquifer depths being a more decisive variable. In this way, groundwater data corresponding to the Moroccan aquifer show it to be deeper than the Spanish aquifer (named Aquifer 23). In Saiss (Morocco), data with greater applicability levels correspond to values closer to the borderlines of the plain, near three rivers in the basin of the Sebou river. On the contrary, the Spanish data show aquifer depths almost uniform on the Western-side, being deeper than on the Eastern-side. These results point out the Guadiana river band nearby areas, lagoons and its tributaries as areas with remarkable rates of applicability. The results provide relevant information regarding the potential of solar energy in such areas, meaning that the applicability of solar water pumping depends on the location. In line with these results, the investments will be higher or lower. It is possible to establish a comparison between these economic requirements and the current expenses incurred by farmers in pumping diesel, see 63 for further information.

In order to provide additional information about the 


\section{Comparison of Solar Resource}

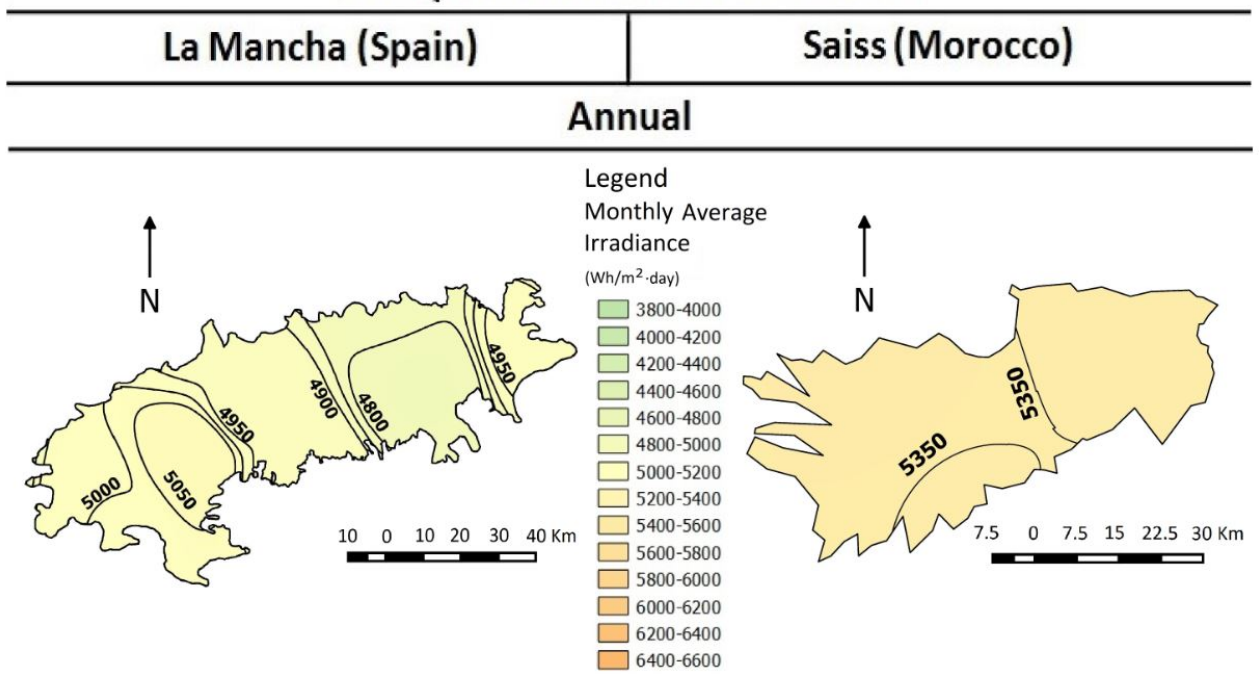

Figure 11: Annual solar resource: comparison of maps

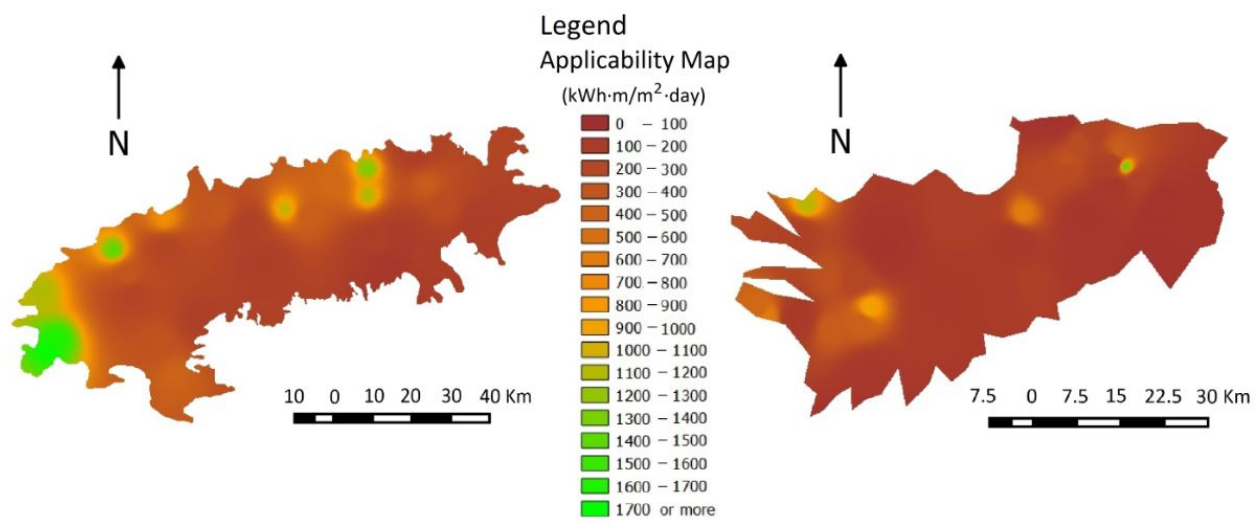

Figure 12: Geographical Analysis of Solar resource: Comparison of applicability layers
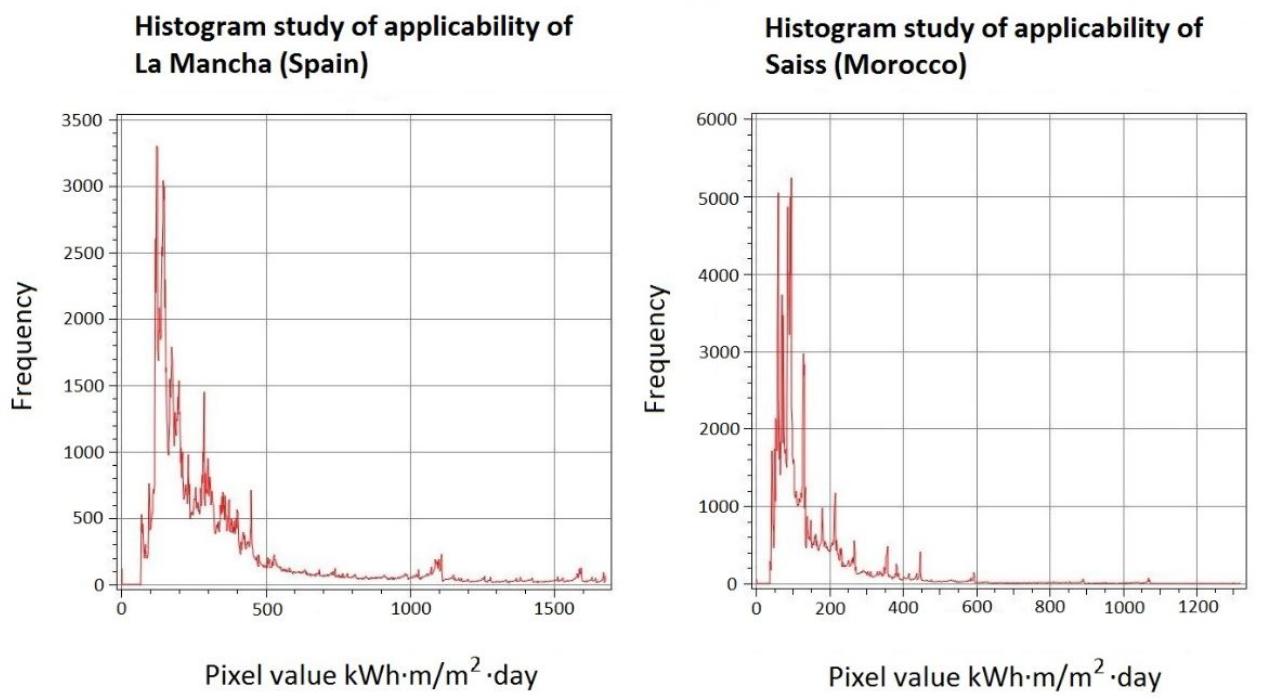

Figure 13: Histogram study of applicability of La Mancha (Spain) and Saiss (Morocco) 
applicability layer, Figure 13 shows the histogram results for these values. As can be seen, for the Spanish case over $80 \%$ of the values are between 44.21 and $486.36 \mathrm{Wh} \cdot \mathrm{m} / \mathrm{m}^{2}$ per day, with an average value of $223.37 \mathrm{Wh} \cdot \mathrm{m} / \mathrm{m}^{2}$ per day. Regarding the Saiss plain (Morocco), these values show that $81.77 \%$ of data are between 44.50 and 222.54 $\mathrm{Wh} \cdot \mathrm{m} / \mathrm{m}^{2}$ per day, presenting a lower standard deviation and an average value of $105.40 \mathrm{Wh} \cdot \mathrm{m} / \mathrm{m}^{2}$ per day.

\subsection{Technical Analysis of Solar Resource and $\mathrm{CO}_{2}$ emis- sions}

A comparison of energy needs and emissions for both locations is carried out in this section. Indeed, the Spanish aquifer has an average applicability value of 223.37 $\mathrm{Wh} \cdot \mathrm{m} / \mathrm{m}^{2}$ per day corresponding to an average annual radiation of $4.87 \mathrm{kWh} / \mathrm{m}^{2}$ per day and with an average aquifer depth of $21.82 \mathrm{~m}$. For the aquifer located in Morocco, the average value of applicability is estimated to be $105.40 \mathrm{Wh} \cdot \mathrm{m} / \mathrm{m}^{2}$ per day, corresponding to an average annual radiation of $5.34 \mathrm{kWh} / \mathrm{m}^{2}$ per day and with an average depth of $50.76 \mathrm{~m}$. Therefore, and by considering both study areas and previous analysis, Figure 14 summarizes the water pumping design to support the requirements, estimating water needs for the same crops. These water requirements are slightly higher for the Saiss plain (Morocco), mostly due to higher average temperatures and higher solar radiation levels. According to the results, the study area of Saiss (Morocco) needs more irrigation time and thus, a higher energy demand in comparison with the Spanish case.

By considering these water necessities, Figures 15 and 16 present an extensive comparison between the proposed solutions based on diesel equipment and PV installation. Different economic costs are estimated for both countries, as a consequence of their energy policies and the increasing pressure on the farmer's life. Moreover, in terms of $\mathrm{CO}_{2}$ emissions, the Saiss plain in Morocco is higher than the same crop in La Mancha (Spain) 64, 65, 66. If PV solution is selected for pumping purposes, and considering the same pattern of crop water demands, in $82.73 \%$ of cases (455015 Ha), La Mancha (Spain) requires a PVinstallation with a power rate of $2800 \mathrm{~W}$. By considering the Morocco case study and also assuming a crop demanding the same amount of irrigation as the vineyard, with the climatic conditions of the Saiss plain, in $81.77 \%$ of cases $(179894 \mathrm{Ha})$, a PV-installation of $8160 \mathrm{~W}$ rate power is necessary 67. Both systems are designed in terms of the power demanded by the crops according to the energy required for the three months that the plant water demand for growth lasts in time interval, coinciding with the hottest summer months in both areas, and it corresponds to the time period between the flowering and maturation of the crop chosen (from June to August). Through the system demand, it is possible to estimate $\mathrm{CO}_{2}$ emissions [68, 69, 70]. Comparing both systems and estimating the emission reduction provided by the energy model change toward a model based on renewables.
Comparing Figures 15 and 16, the energy consumption in the Saiss plain is higher than in the Spanish aquifer, and thus a larger PV installation is required for the same use per Hectare. Along with that, $\mathrm{CO}_{2}$ emissions would be three times higher in the case of a diesel generator in Morocco than in La Mancha (Spain), mainly due to the depth: $72 \%$ higher in Saiss (Morocco) against La Mancha. Nevertheless, it is necessary to point out the low price of fossil fuels in Morocco, which means that this country can still be based on diesel generators for agricultural pumping systems. Finally, the $\mathrm{CO}_{2}$ emission savings for photovoltaic technologies is very favorable with the use of Mono-Si in both countries, although the savings in $\mathrm{CO}_{2}$ emissions are much more desirable in the case of the Saiss plain, being possible to save up to five times more $\mathrm{CO}_{2}$ than in La Mancha (Spain).

\section{Conclusions}

A proposed methodology based on GIS is described to analyze and compare two areas in different Mediterranean countries suitable for the installation of pumping systems by using PV plants through the aggregation of qualitative and quantitative criteria related to both solar resource and aquifer depth. Significant differences in terms of energy mix, climatic conditions and energy policies have been considered, with the aim of providing an extensive and real comparison. From real data corresponding to both locations (Spain and Morocco), a GIS environment is proposed to analyze spatial and temporal variability of the solar resource, as well as the underground aquifers for both areas for pumping irrigation purposes. Additional energy, economic and environmental savings attributed to the replacement of diesel pumps by solar PV installations are also included in the paper.

The results assess the proposed methodology based on GIS to be able to solve multi-dimensional problems related to agriculture sector and energy requirements applied to irrigation processes based on aquifer, water resource control and solar resource integration. In addition, the replacement of current diesel systems by solar pumping installations is also included, estimating the $\mathrm{CO}_{2}$ emission savings for both locations. According to the results, the Saiss aquifer (Morocco) has a higher energy demand to obtain water in comparison with La Mancha (Spain). In terms of $\mathrm{CO}_{2}$ emissions, they would be three times higher in the case of a diesel generator in Morocco than in La Mancha (Spain). Future work is proposed to assess the degree of clustering of plots through agro-energetic cooperatives in order to create irrigation storage facilities. 


\begin{tabular}{|c|c|c|}
\hline La Mancha (Spain) & & Saiss (Morocco) \\
\hline \multicolumn{3}{|c|}{ Pump Desing } \\
\hline 10.82 & Q Max Water pumping $\left(\mathrm{m}^{3} / \mathrm{h}\right)$ & 17.77 \\
\hline 21.82 & $h$ Depth groundwater (HWC) & 50.76 \\
\hline 13 & $\begin{array}{r}h(p g) \text { Pressure in irrigation } \\
\text { network head (HWC) }\end{array}$ & 13 \\
\hline 5 & $h(a)$ Lost by advection (HWC) & 5 \\
\hline 11 & $h(0)$ Other losses (HWC) & 11 \\
\hline 40.82 & $H$ Total pressure ( $\mathrm{HWC}$ ) & 69 \\
\hline 0.9 & $\eta_{m}$ Mechanical performance & 0.9 \\
\hline 0.9 & $\eta_{e}$ Electric performance & 0.9 \\
\hline 1484.63 & $\begin{array}{c}P \text { Power demanded by } \\
\text { the pump }(W)\end{array}$ & 4122.13 \\
\hline 2 & Power (C.V.) & 5.6 \\
\hline
\end{tabular}

Figure 14: Water requirements and pumping design in both areas

\begin{tabular}{|c|c|c|c|c|}
\hline \multicolumn{2}{|c|}{ La Mancha (Spain) } & & \multicolumn{2}{|c|}{ Saiss (Morocco) } \\
\hline \multicolumn{5}{|c|}{ OPTION 1: Diesel generator equipment } \\
\hline \multicolumn{2}{|c|}{1484.63} & Power required $(W)$ & \multicolumn{2}{|c|}{4122.13} \\
\hline \multicolumn{2}{|c|}{$2 \mathrm{KVA}$} & Power of diesel generator standart (W) & \multicolumn{2}{|c|}{$5 \mathrm{KVA}$} \\
\hline \multicolumn{2}{|c|}{1.39} & Consumption $100 \%(\mathrm{l} / \mathrm{h})$ & \multicolumn{2}{|c|}{1.56} \\
\hline \multicolumn{2}{|c|}{0.778} & Emissions $\mathrm{kgCO}_{2} / \mathrm{kWh}$ & \multicolumn{2}{|c|}{0.778} \\
\hline \multicolumn{2}{|c|}{213.78} & Total Energy generated kWh & \multicolumn{2}{|c|}{643.03} \\
\hline \multicolumn{2}{|c|}{200.16} & Total Consumption (I) & \multicolumn{2}{|c|}{246.36} \\
\hline \multicolumn{2}{|c|}{166.32} & Total Emissions $\left(\mathrm{kgCO}_{2}\right)$ & \multicolumn{2}{|c|}{500.27} \\
\hline October 2013 & October 2015 & Price of diesel & October 2015 & October 2013 \\
\hline \multirow[t]{2}{*}{$1.38\left(0.84^{*}\right)$} & $1.09\left(0.78^{*}\right)$ & Price of diesel liter $(€)(D H) \quad$-with subsidized & 7.98 & 8.54 \\
\hline & & Change $€$-DH & 0.75 & 0.76 \\
\hline $275.22\left(168.16^{*}\right)$ & $217.97\left(156.13^{*}\right)$ & Price of diesel in summer $(€)$ & 184.77 & 187.26 \\
\hline
\end{tabular}

Figure 15: Diesel equipment design and $\mathrm{CO}_{2}$ emissions in both areas

\begin{tabular}{|c|c|c|c|c|c|c|c|}
\hline \multicolumn{3}{|c|}{ La Mancha (Spain) } & & & \multicolumn{3}{|c|}{ Saiss (Morocco) } \\
\hline \multicolumn{8}{|c|}{ OPTION 2: PV-Pump } \\
\hline \multicolumn{3}{|c|}{6.813} & PSH & Peak Sun Hours & \multicolumn{3}{|c|}{6.903} \\
\hline \multicolumn{3}{|c|}{8} & $\mathrm{t}$ & Max Hours Operating per day & \multicolumn{3}{|c|}{8} \\
\hline \multicolumn{3}{|c|}{19 은 } & & Optimal angle & \multicolumn{3}{|c|}{139} \\
\hline \multicolumn{3}{|c|}{11.37} & $e D$ & Energy demanded per day ( $\mathrm{kWh}$ ) & \multicolumn{3}{|c|}{32.97} \\
\hline \multirow{2}{*}{\multicolumn{3}{|c|}{$\begin{array}{c}0.75 \\
15.16\end{array}$}} & CS & Coefficient Supply & \multirow{2}{*}{\multicolumn{3}{|c|}{$\begin{array}{l}0.75 \\
43.96\end{array}$}} \\
\hline & & & $\mathrm{TeD}$ & Total Energy demanded per day (kWh) & & 43.96 & \\
\hline \multicolumn{3}{|c|}{255} & $W_{p}$ & Wp per PV-Module & \multicolumn{3}{|c|}{255} \\
\hline \multicolumn{3}{|c|}{0.8} & $\mathrm{Pr}$ & Modules Perfomance Ratio & \multicolumn{3}{|c|}{0.8} \\
\hline \multicolumn{3}{|c|}{11} & № & No Modules & \multicolumn{3}{|c|}{32} \\
\hline \multicolumn{3}{|c|}{2805} & & Installed Power & \multicolumn{3}{|c|}{8160} \\
\hline \multicolumn{3}{|c|}{403.92} & & Total Energy generated kWh & \multicolumn{3}{|c|}{1272.96} \\
\hline CdTe & Mono-Si & Poly-Si & & Technologies & CdTe & Mono-Si & Poly-Si \\
\hline 18 & 47 & 45 & & Emissions $\mathrm{gCO}_{2} / \mathrm{kWh}$ & 18 & 47 & 45 \\
\hline 7.27 & 18.98 & 18.17 & & Total Emissions $\mathrm{kgCO}_{2}$ & 22.32 & 58.29 & 55.81 \\
\hline 159.05 & 147.34 & 148.15 & & $\mathrm{kgCO}_{2}$ emissions avoided & 477.95 & 441.98 & 444.46 \\
\hline
\end{tabular}

Figure 16: $\mathrm{PV}$ system design and $\mathrm{CO}_{2}$ emissions in both areas 


\section{Acknowledgements}

The authors appreciate the EU Marenostrum-Erasmus Mundus Program, which allows us to collaborate with the Moulay Ismail University in Meknes (Morocco). This work has been partially supported by funds, DGICYT and Junta de Andalucía under projects TIN 2014-55024-P and P11-TIC-8001 respectively, and Seneca Foundation 19882GERM-15.

\section{References}

[1] Perspectives on the role of science and technology in sustainable development, U.S. Congress, Office of Technology Assessment OTA-ENV-609, U.S. Congress, Office of Technology Assessment (September 1994).

[2] Energy and Climate Change International Energy Agency, International Energy Agency (2015). URL http://www . iea.org

[3] N. S. Daniele Menniti, Alessandro Burgio, Crecimiento demográfico, desarrollo, recursos energéticos y ambiente: la opción nuclear, DYNA, Energía 81 (9) (Diciembre 2006) 51-57.

[4] P. Fortes, J. Seixas, S. Simoes, J. Cleto, Long term energy scenarios under uncertainty, in: Electricity Market, 2008. EEM 2008. 5th International Conference on European, 2008, pp. 1-6. doi:10.1109/EEM.2008.4579093.

[5] On the influence of carbonic acid in the air upon the temperature of the ground, Philosophical Magazine Series 541 (251) (1896) 237-276.

[6] R. Li, X. Liu, Y. Sun, Integrated Assessment Model for Solar Energy Resource Based on GIS, in: Multimedia Technology (ICMT), 2010 International Conference on, 2010, pp. 1-4. doi:10.1109/ICMULT . 2010.5631316

[7] J. Sánchez-Lozano, M. García-Cascales, M. Lamata, Identification and selection of potential sites for onshore wind farms development in Region of Murcia, Spain, Energy 73 (2014) 311324. doi:http://dx.doi.org/10.1016/j.energy.2014.06.024

[8] T. Weiss, D. Schulz, Development of fluctuating renewable energy sources and its influence on the future energy storage needs of selected european countries, in: Energy (IYCE), 2013 4th International Youth Conference on, 2013, pp. 1-5. doi:10.1109/IYCE. 2013.6604173

[9] Renewable Energies Plan (PER) 2005-2010, Tech. rep., Institute for Energy Diversification and Saving IDAE (2005).

[10] Renewable Energies Plan (PANER) 2011-2020, Tech. rep., Institute for Energy Diversification and Saving IDAE (2010).

[11] J. Sánchez-Lozano, M. García-Cascales, M. Lamata, Evaluation of suitable locations for the installation of solar thermoelectric power plants, Computers \& Industrial Engineering 87 (2015) 343-355. doi:http://dx.doi.org/10.1016/j.cie. 2015.05 .028

[12] M. D. Gómez-López, M. S. García-Cascales, E. Ruiz-Delgado, Situations and problems of renewable energy in the Region of Murcia, Spain, Renewable and Sustainable Energy Reviews 14 (4) (2010) 1253-1262. doi:http://dx.doi.org/10.1016/j. rser.2009.12.015

[13] A. Ghezloun, A. Saidane, N. Oucher, Energy policy in the context of sustainable development: Case of Morocco and Algeria, Energy Procedia 50 (2014) 536-543, technologies and Materials for Renewable Energy, Environment and Sustainability. doi:http://dx.doi.org/10.1016/j.egypro.2014.06.065

[14] F. Tubiello, M. Salvatore, R. C. Golec, A. Ferrara, S. Rossi, R. Biancalani, S. Federici, H. Jacobs, A. Flammini, Agriculture, Forestry and Other Land Use Emissions by Sources and Removals by Sinks, Tech. rep., Climate, Energy and Tenure Division, FAO, 1990-2011 Analysis (March 2014).

[15] J. Domínguez, J. Amador, Geographical information systems applied in the field of renewable energy sources, Computers \& Industrial Engineering 52 (3) (2007) 322-326, planning and Management of Energy and Infrastructure Engineering Projects. doi:http://dx.doi.org/10.1016/j.cie.2006. 12.008

[16] P. Fausto, G. Julio, G. Francisco, G. Heriberto, Estimación del potencial de energía solar en Venezuela utilizando Sistemas de Información Geográfica, Revista Geográfica Venezolana 55 (2014) 27-43.

[17] J. M. Sánchez-Lozano, J. Teruel-Solano, P. L. Soto-Elvira, M. S. García-Cascales, Geographical information systems (GIS) and Multi-Criteria Decision Making (MCDM) methods for the evaluation of solar farms locations: Case study in south-eastern Spain, Renewable and Sustainable Energy Reviews 24 (2013) 544-556. doi:http://dx.doi.org/10.1016/j.rser.2013.03. 019

[18] C. Bengoetxea, F. Rebollo, Energía Renovable y Desarrollo Sostenible, DYNA, Energía 81 (4) (Mayo 2006) 41-44.

[19] G. Batsukh, D. Ochirbaani, C. Lkhagvajav, N. Enebish, B. Ganbat, T. Baatarchuluun, K. Otani, K. Sakuta, Evaluation of solar energy potentials in Gobi desert area of Mongolia, in: Photovoltaic Energy Conversion, 2003. Proceedings of 3rd World Conference on, Vol. 3, 2003, pp. 2262-2264 Vol.3.

[20] J. N. Mayer, S. Philipps, N. S. Hussein, T. Schlegl, C. Senkpiel, Current and future cost of photovoltaics, Tech. rep., Agora Energiewende, long-term Scenarios for Market Development, System Prices and LCOE of Utility-Scale PV Systems (February 2015).

[21] IRENA Working Paper Solar Photovoltaics, Tech. rep., IRENA International Renewable Energy Agency, RENEWABLE ENERGY TECHNOLOGIES: COST ANALYSIS SERIES Volume 1: Power Sector (June 2012).

[22] B. Sorensen, GIS management of solar resource data, Solar Energy Materials and Solar Cells 67 (14) (2001) 503-509. doi: http://dx.doi.org/10.1016/S0927-0248(00)00319-6

[23] M. Islam, I. Kubo, M. Ohadi, A. Alili, Measurement of solar energy radiation in Abu Dhabi, (UAE), Applied Energy 86 (4) (2009) 511-515. doi:http://dx.doi.org/10.1016/j. apenergy.2008.07.012

[24] H. Grossi Gallegos, Disponibilidad y características de la radiación solar en Sudamérica, Solar Safe Water.

[25] A. Gastli, Y. Charabi, Solar electricity prospects in oman using gis-based solar radiation maps, Renewable and Sustainable Energy Reviews 14 (2) (2010) 790 - 797. doi:http: //dx.doi.org/10.1016/j.rser.2009.08.018

[26] E. Zell, S. Gasim, S. Wilcox, S. Katamoura, T. Stoffel, H. Shibli, J. Engel-Cox, M. A. Subie, Assessment of Solar Radiation Resources in Saudi Arabia, Solar Energy 119 (2015) 422-438. doi:http://dx.doi.org/10.1016/j.solener.2015.06.031

[27] A. Neshat, B. Pradhan, M. Dadras, Groundwater vulnerability assessment using an improved DRASTIC method in GIS, Resources, Conservation and Recycling 86 (2014) 74-86. doi: http://dx.doi.org/10.1016/j.resconrec.2014.02.008

[28] M. G. Salim, Selection of groundwater sites in egypt, using geographic information systems, for desalination by solar energy in order to reduce greenhouse gases, Journal of Advanced Research 3 (1) (2012) 11 - 19. doi:http://dx.doi.org/10.1016/ j.jare.2011.02.008

[29] L. C. Kelley, E. Gilbertson, A. Sheikh, S. D. Eppinger, S. Dubowsky, On the feasibility of solar-powered irrigation, Renewable and Sustainable Energy Reviews 14 (9) (2010) 2669 2682. doi:http://dx.doi.org/10.1016/j.rser.2010.07.061

[30] Mancha Occidental, Tech. rep., Instituto Tecnológico Geominero de España (1989).

[31] M. García Rodríguez, M. Llamas Madurga, Características geológicas del borde suroccidental de la unidad hidrogeológica 04.04 y su influencia sobre la hidrogeología de las tablas de daimiel, Geogaceta 20 (6) (1996) 1271-1273.

[32] Etude du Schema Regional dÁmengement du Territoire de la Region Fes-Boulemane, Tech. rep., Ministere de LH́abitat, de LÚrbanisme et de la Politique de la Ville. Direction Regionale de lH́abitat, de LÚrbanisme et la Politique de la Ville de la Region Fés-Boulemane, Roaume Du Maroc, Ministere de L 'Interieur, Wilaya e la Region Fes-Boulemane, Conseil Regional de Fes-Boulemane, phase I: Diagnostic territorial tratégique, Etape 1: Raportts Sectoriels Le Milieu Naturel, Les Ressources et Lénvironnement (June 2013).

[33] A. Essahlaoui, A. E. Ouali, Determination de la structure 
géologique de la partie Sud de la plaine du Saiss (bassin de Meknés-Fés, Maroc) par la méthode géoélectrique, Bulletin of Engineering Geology and the Environment 62 (2003) 155-166.

[34] F. Amraoui, Contribution a la connaissance des aquiféres karstiques: cas du Lias de la plaine du Sais et du Causse Moyen Atlasique tabulaire (Maroc) (July 2005)

[35] Etude de la Faisabilite de Transfert du Haut Sebou vers la Plaine du Saiss, Tech. rep., Agence du Bassin Hydraulique du Sebou, rapport de synthése (Novembre 2006).

[36] R. F. Bangash, Analysis of [c]limate Change Impact on Hydrologycal Ecosystem Services and Water Allocation in Water Scarce Mediterranean River Basins (January 2014).

[37] A. Iglesias, L. Garrote, F. Flores, M. Moneo, Challenges to manage the risk of water scarcity and climate change in the mediterranean, Water Resources Management 21 (5) (2007) 775-788. doi:10.1007/s11269-006-9111-6.

[38] I. Theesfeld, Water politics and development cooperation: Local power plays and global governance: Political power play in Bulgaria's irrigation sector reform, springer Edition, W. Scheumann and S. Neubert and M. Kipping, Heidelberg, Berlin, 2008.

[39] E. Kaptijn, Communality and power: Irrigation in the zerqa triangle, jordan, Water History 2 (2) (2011) 145-163.

[40] P. Mathieu, A. Benali, O. Aubriot, Dynamiques institutionnelles et conflit autour des droits d'eau dans un systme d'irrigation traditionnel au maroc, Tiers-Monde 42 (166) (2001) 353-374. doi:10.3406/tiers.2001.1509

[41] J. Jani, Gis as a tool for modelling groundwater flow, in: Business, Engineering and Industrial Applications (ISBEIA), 2012 IEEE Symposium on, 2012, pp. 513-517. doi:10.1109/ISBEIA . 2012.6422939.

[42] M. M. Moreno, J. L. Gutiérrez, L. M. Cortina, Hydrogeological characteristics and groundwater evolution of the western La Mancha unit: the influence of the wet period 2009-2011, Boletín Geológico y Minero 123 (2) (2012) 91-108.

[43] M. Mejías Moreno, Contribución al conocimiento hidrogeológico de la Unidad Hidrogeológica 04.04 (Mancha Occidental). Análisis de la evolución piezométrica, Tech. rep., Dirección de Hidrogeología y Aguas Subterráneas. IGME.

[44] Plan Especial del Alto Guadiana PEAG, Anejo I. Definición de escenarios de uso del agua en la agricultura del Acuífero 23, Tech. rep., Dirección de Hidrogeología y Aguas Subterráneas. IGME.

[45] J. Margat, Carte hydrogéologique du basin de Fès-Meknès au 1/100,000, Agence du Bassin Hydrauliques de Sebou, Fès.

[46] S. de Estado de Energía, La Energía en España, Tech. rep., Ministerio de Industria, Energía y Turismo. Gobierno de España (2013).

[47] Informe del Sistema Eléctrico Español, Tech. rep., REE Red Eléctrica de España (2014).

[48] Mohammed Tawfik Mouline, La Securité Energétique du Maroc : Etat des lieux et perspectives, Tech. rep., Ministére de lÉnergie, des Mines, de lÉau et de lÉnvironnement (2012).

[49] B. Sliz-Szkliniarz, J. Vogt, Gis-based approach for the evaluation of wind energy potential: A case study for the kujawskopomorskie voivodeship, Renewable and Sustainable Energy Reviews 15 (3) (2011) 1696 - 1707. doi:http://dx.doi.org/10. $1016 / \mathrm{j} . \mathrm{rser} .2010 .11 .045$

[50] M. Hugentobler, Encyclopedia of GIS, Springer US, Boston, MA, 2008, Ch. Quantum GIS, pp. 935-939. doi:10.1007/ 978-0-387-35973-1_1064

[51] sistema de informacin geogrfica qgis, Open Source Geospatial Proyecto Fundacin

[52] H. Broesamle, H. Mannstein, C. Schillings, F. Trieb, Assessment of solar electricity potentials in north africa based on satellite data and a geographic information system, Solar Energy 70 (1) (2001) 1-12. doi:http://dx.doi.org/10.1016/ S0038-092X (00) 00126-2

[53] F. Qiang, L. Wei-ye, W. Xiao-wei, Gis evaluation on groundwater resources of sanjiang plain, china, in: Wireless Communications, Networking and Mobile Computing, 2007. WiCom 2007. International Conference on, 2007, pp. 5995-5997. doi:
10.1109/WICOM.2007.1470

[54] K. Calvert, Geomatics and bioenergy feasibility assessments: Taking stock and looking forward, Renewable and Sustainable Energy Reviews 15 (2) (2011) 1117 - 1124. doi:http://dx. doi.org/10.1016/j.rser.2010.11.014

[55] E. B. Mondino, E. Fabrizio, R. Chiabrando, A \{GIS $\}$ tool for the land carrying capacity of large solar plants, Energy Procedia 48 (2014) 1576 - 1585, proceedings of the 2nd International Conference on Solar Heating and Cooling for Buildings and Industry (SHC 2013). doi:http://dx.doi.org/10.1016/ j.egypro.2014.02.178

[56] A. Gastli, Y. Charabi, Siting of large pv farms in Al-Batinah region of Oman, in: Energy Conference and Exhibition (EnergyCon), 2010 IEEE International, 2010, pp. 548-552. doi: 10.1109/ENERGYCON.2010.5771742

[57] M. Bea, S. Montesinos, C. Morugán, S. Moraleda, Análisis comparativo de las superficies regadas en los acuíferos del campo de montiel y la mancha occidental en el período 2004-2008 comparative analysis of irrigated areas in campo de montiel and la mancha occidental, Revista de Teledetección 2010 (34) (2009) $22-28$.

[58] Belkhiri, Gestion integreé des ressources en eau, protection de la ressource, Tech. rep., Revue HTE lÁgence du Bassin Hydraulique du Sebou, bassin du Sebou (June 2007).

[59] S. d Etat chargé de lÉau et de lÉnvironnement, Etude dáctualisation du plan directeur dámenagement integre des ressources en eau du bassin hydraulique de sebou, Tech. rep., Secrétariat dÉtat chargé de lÉau et de lÉnvironnement. Agence du Bassin Hydraulique du Sebou (Septembre 2011).

[60] E. Ghoneim, F. El-Baz, Mapping water basins in the eastern sahara by srtm data, in: Geoscience and Remote Sensing Symposium, 2008. IGARSS 2008. IEEE International, Vol. 1, 2008, pp. I-1-I-4. doi:10.1109/IGARSS.2008.4778777

[61] J. Ramos, H. M. Ramos, Solar powered pumps to supply water for rural or isolated zones: A case study, Energy for Sustainable Development 13 (3) (2009) 151 - 158. doi:http://dx.doi.org/ 10.1016/j.esd.2009.06.006

[62] L. Mitas, H. Mitasova, Spatial interpolation, Geographical information systems: principles, techniques, management and applications 1 (1999) 481-492.

[63] A. Rubio-Aliaga, M. S. García-Cascales, A. Molina-García, J. M. Sánchez-Lozano, Sistemas de infomación geográfica para optimización e integración de energía solar fotovoltaica en zonas agrícolas con dificultades energéticas e hídricas, XIX Congreso Internacional de Dirección e Ingeniería de Proyectos Granada.

[64] E. Alsema, V-2 - energy pay-back time and $\{\mathrm{CO} 2\}$ emissions of $\{\mathrm{PV}\}$ systems, in: T. Markvart, L. Castañer (Eds.), Practical Handbook of Photovoltaics, Elsevier Science, Amsterdam, 2003, pp. 869-886. doi:http://dx.doi.org/10.1016/ B978-185617390-2/50038-6

[65] V. M. Fthenakis, H. C. Kim, E. Alsema, Emissions from photovoltaic life cycles, Environmental Science \& Technology 42 (6) (2008) 2168-2174, pMID: 18409654. doi:10.1021/es071763q

[66] K. Kato, A. Murata, K. Sakuta, Energy pay-back time and lifecycle co2 emission of residential pv power system with silicon pv module, Progress in Photovoltaics: Research and Applications 6 (2) (1998) 105-115. doi:10.1002/(SICI) 1099-159X(199803/ 04) 6:2<105: :AID-PIP212>3.0.CO;2-C

[67] H. J. Helikson, D. Z. Haman, C. D. Baird, Pumping water for irrigation using solar energy, EES-Florida Cooperative Extension Service.

[68] V. Fthenakis, E. Alsema, Photovoltaics energy payback times, greenhouse gas emissions and external costs: 2004-early 2005 status, Progress in photovoltaics: research and applications 14 (3) (2006) 275-280.

[69] V. Fthenakis, H. C. Kim, R. Frischknecht, M. Raugei, P. Sinha, M. Stucki, Life cycle inventories and life cycle assessment of photovoltaic systems, International Energy Agency (IEA) PVPS Task 12.

[70] M. P. Tsang, G. W. Sonnemann, D. M. Bassani, Life-cycle assessment of cradle-to-grave opportunities and environmen- 
tal impacts of organic photovoltaic solar panels compared to conventional technologies, Solar Energy Materials and Solar Cells (2016) doi:http://dx.doi.org/10.1016/j.solmat.

2016.04 .024 